\title{
Three R's: reduce, recycle and reuse; Kathmandu Medical College: An eco-friendly hospital
}

\section{Rijal R}

Rika Rijal, Intern, Kathmandu Medical College Teaching Hospital, Kathmandu, Nepal

\begin{abstract}
A ccording to World Health Organization, hospital waste includes all the waste generated by healthcare establishments, research facilities and laboratories. In addition, it includes the waste originating from "minor" or "scattered" sources such as dialysis, insulin injections etc'. With the ever increasing population and health care needs, there is mushrooming of health care centers and institute. An increase in health care has direct relation with generation of hospital waste. This means directly or indirectly putting the health of workers and general population at risk.
\end{abstract}

We being health professionals are mostly concerned about treating patients that present to us. We do clinical evaluation and treat them accordingly. But what about the unforeseen disease that we ourselves are generating within the hospital premises through hospital waste? Shouldn't we really be doing something about it?

Every year thousands of people are affected by the similar problems. We see only tip of the iceberg but the main problem lies neglected just like the ice underwater ${ }^{2}$. The hospital generated waste can be contaminated with HIV, Hepatitis B and other deadly bacteria and viruses ${ }^{3}$. To add on to this, our municipality doesn't have provision of segregating waste. The hospital generated waste when mixed with other non hospital waste produce harmful gases. These gases like dioxins, furans are injurious to health of all the living organisms ${ }^{4}$. Similarly, the mercury that is used in thermometers if broken and contaminated can affect brain, kidney and other organs in long term ${ }^{5}$. Needle prick injury every year is claiming thousands of lives with HIV and hepatitis particularly children and scavengers ${ }^{3}$. Many of them face the door of death as a result of these deadly diseases and only a

Address for correspondence

Dr. Rika Rijal

Intern

Kathmandu Medical College Teaching Hospital

Kathmandu, Nepal

E-mail: rikarjl@gmail.com few make through with the social stigmata throughout their lives.

Is it justifiable for us to put others health at risk? Still, should we not be thinking that management of hospital waste is a burning issue?

Medical institute and hospitals are important sources for generation of infectious wastes ${ }^{1,3}$. Each hospital has its generation and transportation of waste according to its location and availability of materials. As for example, in Paropakar Maternity and Women's hospital an average of $400 \mathrm{~kg}$ of waste is generated per day ${ }^{6}$. With such huge amount of waste generated from even a single hospital, it is of dire importance to manage hospital generated waste properly in order to avoid many unseen health and environmental risks'.

Kathmandu Medical College Teaching Hospital (KMCTH) is located in Sinamangal, a densely populated part of the Kathmandu city. Have we ever wondered what impact does the waste produced from this center have an impact among the workers and people living nearby? Considering the alarming situation, Health Care Foundation Nepal (HECAF), which is a national non-governmental, not for profit organization with a mandate to work in health care, environment health and emergency health, conducted a diagnostic healthcare waste assessment in KMCTH in 2013. According to the result from this assessment, average total waste generation was $296 \mathrm{~kg} /$ day; waste generation rate was $1.17 \mathrm{~kg} /$ patient/day. Eighty five percent of the total waste was risk waste, comprising of syringe, dressing pad, blood bag, etc. While these wastes were incinerated, fifteen percent of the total waste was sent to landfill sites.

So, a planning was done for the smooth working of waste management and a panel of members were created which worked and coordinated on a common principle i.e. segregation of wastes at the source. Color-coding was done to identify the content of container each labeled in Nepali and English for user convenience ${ }^{7}$. The 
staffs in the ward are being trained and then they are asked to teach other staffs in the hospital. With this chain of communication, it gained lot of attention and in no time is being conducted without fail. With full support of doctors, nurses and other staffs, this system is in the verge of being implied in all wards in hospital. This vital step will prove to be fruitful in the long run for upcoming future generations as well.

In April 2016, KMCTH became member of the international Global Green and Healthy Hospitals (GGHH) network along with 4000 other member hospitals ${ }^{8}$. Out of the 10 goals of GGHH, our hospital is currently working on two goals of waste and energy ${ }^{8}$. $\mathrm{KMCTH}$ is one of the few institutions in Nepal that has

\section{REFERENCES}

1. United Nation Environment Programme and World Health Organization: Preparation of National Health-Care Waste Management Plans in SubSaharan Countries. [Online]. 2005. [cited 2013 Feb 23]. Available from: URL: http://whqlibdoc. who.int/ publications/2005/924154662X.pdf

2. Rajkumari N, Thanbuana BT, John NV, Gunjiyal J, Mathur P, Mishra MC. A prospective look at the burden of sharps injuries and splashes among trauma health care workers in developing countries: true picture or tip of iceberg. Injury. 2014;45(9):14708. Available from: https://www.journals.elsevier. com/injury

3. Michael $\mathrm{OH}$, Scott DH, Jason SH and Piero LO. Health care waste management: a neglected and growing public health problem worldwide. Tropical Medicine and International Health. 2009;14 (11):1-4.

4. Matsui M, Kashima $Y$, Kawano M, Matsuda M, Ambe K, Wakimoto $T$, et al. Dioxin-like potencies and extractable organohalogens (EOX) in medical, municipal and domestic waste incinerator ashes marched a step towards eco friendly and sustainable environment.

Let's learn not to mix all waste together. Let's look and throw in respective bins. Let's try not to mix degradable and non degradable waste. Let's add 3R's to our daily routine starting from home: Reduce, Recycle and Reuse. This will automatically reduce more than half of the waste. Let's learn not to throw bio hazard waste here and there. Let's talk and ask questions. Communication is a key. Let's live and let others live. A healthy person means a healthy family; a healthy family means a healthy society, a healthy nation and finally a healthy world. So health lies in your hand. Start working for it, today.

in Japan. Chemosphere. 2003 Dec;53(8):971-80. Available from: http://dx.doi.org/10.1016/S00456535(03)00587-3

5. World Health Organization. Mercury in health care. Geneva: World Health Organization;2005. Available from : http://www.who.int/water_sanitation_health/ medicalwaste/me rcury/en/index.html

6. Paropakar Maternity and Women's Hospital Waste Management. Global Green and Healthy Hospitals; 2016 Aug. Available from: http://www. hospitalesporlasaludambiental.net/wp-content/ uploads/2016/08/Leadership-Waste-and-EnergyWaste-Management-Paropakar-Maternity-andWomens-Hospital-Nepal.pdf

7. Department of Health Service. Health Care Waste Management Guidelines 2008/9: Kathmandu, Nepal: Department of Health Service; 2009.

8. Global Green and Healthy Hospitals Annual Progress Report. Argentina: Health Care Without Harm; 2014. Available from: http://www.greenhospitals. net/wp-content/uploads/2016/07/GGHH-AnnualReport-2014.pdf 